\title{
Investigation the kinetics of the process of destruction organic contaminations wastewater production margarine
}

Vashkurak U.Yu., Shevchuk L.I.

Vaskurak U.Yu., National University "Lviv Polytechnic", Department of Technology of Organic Products, St. Y. Square 2, UlianaVashkurak@gmail.com

Shevchuk LI, National University "Lviv Polytechnic", Department of Technology of Organic Products, St. Y.

Square 2, shev.lili2206@gmail.com

The kinetics of the cavitational wastewater treatment process of the production of magragin from organic contaminants in the atmosphere of gases of different nature has been investigated. The comparative characteristics effective constants of the rates of destruction of organic substances and the coefficients of approximation are given.

Key words: cavitation, wastewater, kinetics, effective constants of the rates

The wastewater of the fat and oil industry has a wide range of pollutants, therefore the way of its neutralization and the choice of processing method should ensure their complete disposal. The diverse nature and concentration of the pollutant in sewage in many cases do not allow to achieve the required quality of treatment by traditional methods [1]. In this case, technologies that use physical and chemical phenomena can be promising for the purification of natural water and sewage. One of the promising ways to improve water purification technologies is the use of cavitation phenomena. Cavitation technologies are environmentally friendly ways of improving the efficiency of technological processes of water purification [2]. The cost and efficiency of the cavitational water treatment process depends on the degree of their pollution, technologies and equipment which are used for their treatment.

The object of the study was wastewater of the JSC "Lviv Fat and oil plant", a branch of margarine. Output values of chemical oxygen demand (COD) are in the range (705-1450) $\mathrm{mgO}_{2} / \mathrm{dm}^{3}$. Studying the kinetics of the process of destruction of organic compounds, the data of the curves are rectified in half-logarithmic coordinates $\ln \left(\mathrm{COD} / \mathrm{COD}_{0}\right)=\mathrm{f}(\mathrm{t})$, which suggests that this process can be described by the kinetic equation of the first order, and the tangent angle $\operatorname{tg} \alpha=-\mathrm{k}$.

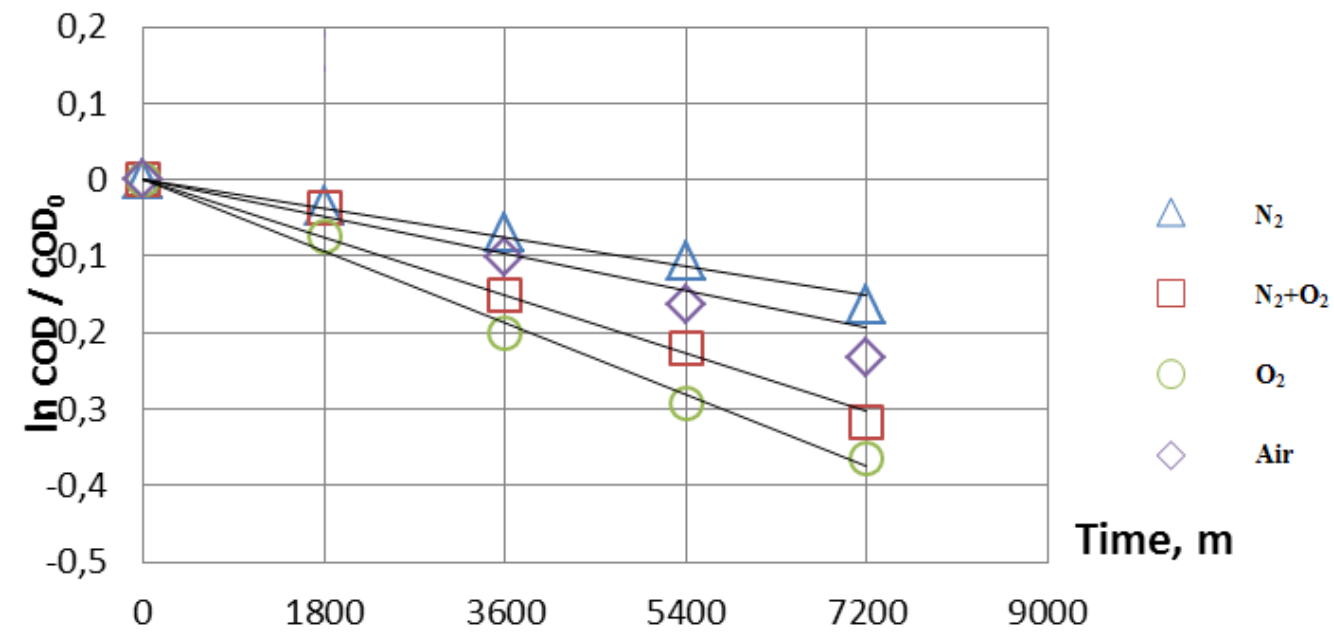

Fig. 1. Semi-logarithmic dependence of the ratio of COD / $\mathrm{COD}_{0}$ of wastewater JSC "Lviv Fat and oil plant"of from time under different process conditions

At the action of the studied gases alone Fig. 1, the lowest result is achieved with nitrogen bubbling, the effective constants of the rates is $0.2 * 10^{-4} \mathrm{~m}^{-1}$. Investigating the influence of the air, it was established that during its bubbling the effective constants of the rates is $0.3 * 10^{-4} \mathrm{~m}^{-1}$. A little bit better result when giving a mixture of nitrogen and oxygen gases in the ratio of 1: 1, the effective constants of the rates is of $0.4 * 10^{-4} \mathrm{~m}^{-1}$. The highest purifying effect is achieved with oxygen bubbling, the effective rate constant for water purification is $0,5^{*} 10^{-4} \mathrm{~m}^{-1}$. 


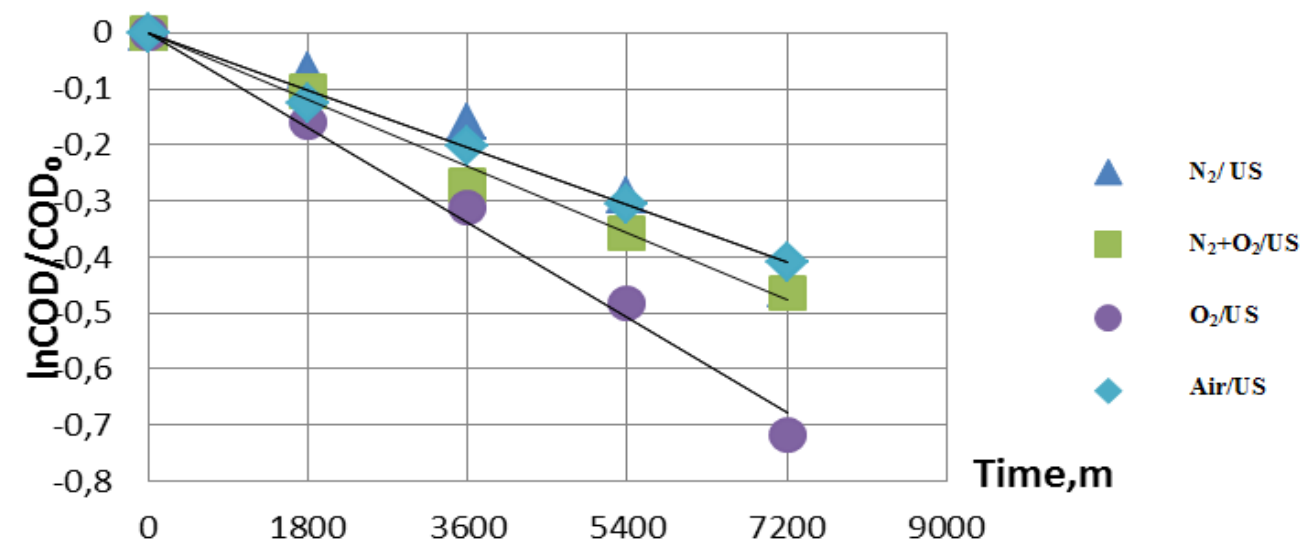

Fig. 2. Semi-logarithmic dependence of the ratio COD / $\mathrm{COD}_{0}$ of wastewater of the JSC "Lviv Fat and oil plant" from time in the presence of ultrasound under different process conditions

Bubbling the gases with different nature with ultrasonic fluctuations substantially improves the purification of investigated sewage, fig. 2. The greatest purification effect is obtained by oxygen bubbling in the US field, the effective rate constant for water purification is $0.9 * 10^{-4} \mathrm{~m}^{-1}$. In the common action of the ultrasound with a mixture of gases of nitrogen and oxygen in the ratio 1: 1, the effective rate constant decreased to $0,7 * 10^{-4} \mathrm{~m}^{-1}$. When using air from US and nitrogen from US, we observe similar values of the effective rate constant $-0.6 * 10^{-4} \mathrm{~m}^{-1}$.

Therefore, as we can see from Table 1, the obtained values of the effective constants of the rate of destruction of organic compounds in sewage under cavitation conditions are 1.75-3 times higher compared with the action of the gases itself.

Table 1.

Comparative characteristic of effective constants of the rates of the process of cleaning wastewater of production margarine from organic contaminants in presence of gases of different nature

\begin{tabular}{|c|c|c|c|c|}
\hline \multirow{2}{*}{$\begin{array}{l}\text { Conditions of the } \\
\text { process }\end{array}$} & \multicolumn{2}{|c|}{$\mathrm{k}^{*} 10^{4}, \mathrm{~m}^{-1}$} & \multicolumn{2}{c|}{$\mathrm{R}$} \\
\cline { 2 - 5 } & Without US & With US & Without US & With US \\
\hline $\mathrm{N}_{2}$ & 0,2 & 0,6 & 0,955 & 0,984 \\
\hline $\mathrm{O}_{2}$ & 0,5 & 0,9 & 0,990 & 0,991 \\
\hline $\mathrm{N}_{2}+\mathrm{O}_{2}$ & 0,4 & 0,7 & 0,974 & 0,989 \\
\hline Air & 0,3 & 0,6 & 0,502 & 0,994 \\
\hline
\end{tabular}

It was investigated that the cavitational process of wastewater treatment from organic contaminants, regardless of the nature of the bubbled gas, can be described by applying the kinetic equation of the first order, the highest purification effect is obtained with the common action of oxygen and ultrasound in cavitation conditions.

1. Saban V. Z. Kontrol za stanom i oxoronoyu poverxnevy`x ta pidzemny’x vod u procesi sporudzhennya ta ekspluataciyi sverdlovy`n / V.Z. Saban, Ya.M. Semchuk // Naukovy`j visny`k Ivano-Frankivs`kogo nacional`nogo texnichnogo universy`tetu nafty` i gazu. - 2009. - \#1 (19).

2. Shevchuk L.I., Starchevs`ky`j V.L. Kavitaciya.Fizy`chni,ximichni, biologichni ta texnologichni aspekty`Vy`davny`tvo L`vivs`koyi politexniky`, 2014 273-280 s. 